\title{
Efektivitas Model Flipped Classroom pada Pembelajaran Fisika Ditinjau dari Self Efficacy dan Penguasaan Konsep Siswa
}

\author{
Pipit Apriyanah $^{1 *}$, I Dewa Putu Nyeneng ${ }^{2}$, dan Wayan Suana ${ }^{3}$ \\ 1,2,3Prodi Pendidikan Fisika Universitas Lampung \\ JI. Prof. Dr. Soemantri Brojonegoro No.1, Bandar Lampung Indonesia \\ *E-mail: pipitapriana11@gmail.com
}

\begin{abstract}
Abstrak
Penelitian ini bertujuan untuk mengetahui efektivitas model Flipped Classroom pada pembelajaran Fisika ditinjau dari self efficacy dan penguasaan konsep siswa. Penelitian ini dilaksanakan di salah satu SMA Negeri di Bandar Lampung dengan sampel penelitian 22 siswa kelas $X \mathrm{MIA}_{1}$ sebagai kelas eksperimen dan 21 siswa kelas $\mathrm{X} M I \mathrm{~A}_{2}$ sebagai kelas kontrol. Desain penelitian yang digunakan adalah Pretest-Posttest Control Group Design. Hasil uji ANCOVA self efficacy adalah $F_{\text {hitung }}>F_{\text {tabel }}(15,28>4,09)$ dan penguasaan konsep adalah $F_{\text {hitung }}>F_{\text {tabel }}(15,49>4,09)$. Dapat dinyatakan bahwa terdapat perbedaan rata-rata self efficacy dan penguasaan konsep siswa pada kelas eksperimen dan kelas kontrol yang artinya menerapkan model Flipped Classroom pada proses pembelajaran memberikan pengaruh yang signifikan terhadap self efficacy dan penguasaan konsep siswa.Kesimpulan dari penelitian ini adalah model pembelajaran Flipped Classroom dapat meningkatkan self efficacy dan kemampuan penguasaan konsep siswa, hal ini ditunjukkan dengan adanya perbedaan rata-rata $\mathrm{N}$-Gain self efficacy pada kelas eksperimen 0,75 dengan kategori tinggi dan $N$-gain penguasaan konsep pada kelas eksperimen 0,70 dengan kategori tinggi.
\end{abstract}

Kata kunci: Flipped Classroom, Self Efficacy, Penguasaan Konsep

\begin{abstract}
This research aimed to find out the effectiveness of Flipped Classroom model to self efficacy and student concept mastery. This Research was conducted at SMAN in Bandar Lampung. The sample of this research was 22 students of $X M I A_{1}$ as an experimental class and 21 students of $X M I A_{2}$ as a control class. The research design used was Pretest-Posttest Control Group Design. Based on the result of self efficacy ANCOVA test with $F_{\text {count }}>F_{\text {table }}$ $(15,28>4,09)$ and the result of concept mastery with $F_{\text {count }}>F_{\text {table }}(15,49>4,09)$, it can be stated that there are differences in mean of self efficacy and mastery of student concepts in the experimental class and control class which means that Flipped Classroom gives a significant impact to the self efficacy and student concept mastery. The conclusion of this research is Flipped Classroom learning model can improve self efficacy and ability to master student concept, this is indicated by the average difference of $\mathrm{N}$-Gain self efficacy in experimental class 0.75 with high category and $\mathrm{N}$-gain mastery of concept in experimental class 0,70 with high category.
\end{abstract}

Keywords: Flipped Classroom, Self Efficacy, Concept Mastery

\section{PENDAHULUAN}

Proses pembelajaran abad 21 menekankan bahwa proses pembelajaran harus berpusat pada siswa. Guru tidak lagi sebagai pemeran utama di kelas, melainkan memberi kesempatan kepada siswa untuk aktif mengemukakan pendapatnya. Metode mengajar yang menempatkan guru sebagai pusat kegiatan pembelajaran dinilai kurang memadai untuk melaksanakan proses pembelajaran di abad 21, karena siswa hanya akan mendengarkan apa yang disampaikan guru dan hal itu dianggap kurang mengeksplorasi wawasan siswa serta tidak sesuai dengan minat, kemampuan, dan cara belajar yang dimiliki setiap individu siswa.

Adapun tujuan yang ingin dicapai dari proses pembelajaran yang berpusat pada siswa menurut Trinova (2013) adalah siswa diharapkan mampu memiliki keleluasaan untuk berperan aktif dan mandiri untuk membangun pengetahuan serta mencapai kompetensinya dengan sumber-sumber informasi yang diperolehnya sendiri melalui proses pembelajaran aktif, interaktif, kolaboratif, dan kooperatif.

Kenyataannya, pada saat ini sebagian besar kegiatan pembelajaran di sekolah masih berpusat 
pada guru sebagai pentransfer pengetahuan, sehingga aktivitas siswa di kelas menjadi pasif, kaku dan membosankan, contohnya seperti yang dialami oleh siswa kelas X SMAN 16 Bandar Lampung.

Berdasarkan sebaran angket siswa yang dilakukan peneliti pada siswa kelas X SMAN 16 Bandar Lampung kebanyakan dari mereka mengalami kesulitan saat mengikuti pembelajaran Fisika, baik saat memahami materi, latihan soal, atau eksperimen. Siswa berpendapat bahwa model pembelajaran yang diterapkan guru tidak menyenangkan karena guru menggunakan model konvensional/ceramah.

Siswa mengalami kesulitan saat mengerjakan PR di rumah karena tidak memahami materi yang dijelaskan oleh guru di kelas. Hal ini berpengaruh pada prestasi belajar siswa yang menurun. Guru Fisika rutin memberikan pekerjaan rumah, hanya saja masalah yang dihadapi adalah ketika siswa tidak bisa mengerjakan pekerjaan rumah yang diberikan. Sebagian siswa beralasan mereka sulit mengerjakan pekerjaan rumah karena siswa kurang memahami materi, lupa rumus, dan lupa konsep.

Dari uraian tersebut di atas menunjukkan bahwa membelajarkan materi Impuls dan Momentum dirasa kurang efektif jika dilakukan dengan model konvensional/ceramah. Hal ini dibuktikan dengan masih banyaknya siswa tidak bisa mengerjakan pekerjaan rumah yang diberikan dengan alasan kurang memahami materi, lupa rumus, dan lupa konsep.

Dibutuhkan model pembelajaran yang mampu mengatasi masalah-masalah yang dialami siswa tersebut. Masalah tersebut bisa diatasi dengan menerapkan model pembelajaran yang didalamnya melaksanakan proses pembelajaran yang berpusat pada siswa, salah satunya adalah model pembelajaran Flipped Classroom.

Model pembelajaran Flipped Classroom adalah suatu model pembelajaran terbalik (Flipped) dari model pembelajaran yang biasa diterapkan guru di kelas. Biasanya guru di kelas mengajarkan materi dengan ceramah lalu memberikan tugas di rumah sebagai tindak lanjut, tetapi dalam Flipped Classroom materi terlebih dahulu diberikan kepada siswa berupa video pembelajaran yang harus di tonton dan dipahami serta mencatat apa saja yang tidak dimengerti dari video tersebut. Sebaliknya, sesi pembelajaran dikelas yaitu diskusi dan mengerjakan tugas. Dalam Flipped Classroom guru berperan sebagai fasilisator.

Basal (2015: 29) dalam Apriyanti dkk. (2017) menyatakan bahwa Flipped Classroom adalah sebuah metode pembelajaran dimana peserta didik belajar teori sendiri dan di dalam kelas belajar dengan menerapkan teori yang dipelajari sebelumnya melalui media pembelajaran.

Adapun desain proses pembelajaran Flipped Classroom secara umum menurut Sihaloho (2017) adalah pembelajaran diawali dengan menonton video pembelajaran secara mandiri di rumah ditemani dengan LKPD pendamping video untuk memastikan peserta didik mengikuti pembelajaran mandiri non tatap muka. Pembelajaran tatap muka di kelas berupa tanya jawab mengenai soal-soal yang ada di LKPD pendamping video dan dilanjutkan dengan diskusi dengan LKPD lain yang memuat kegiatan percobaan, pengamatan, dan latihan soal.

Beberapa penelitian yang bertujuan untuk mengetahui efektivitas menggunakan model Flipped Classrroom mengungkapkan adanya pengaruh saat menerapkan model pembelajaran tersebut di kelas, salah satunya hasil penelitian penelitian oleh Rokhaniyah (2017) menyatakan bahwa Flipped Classroom memberikan efek yang positif bagi siswa dilihat dari peningkatan prestasi akademik. Berdasarkan penelitian yang dilakukan oleh Rindaningsih (2018) menunjukkan model pembelajaran Flipped Classroom memberikan pengaruh yang kuat dalam mengasah keterampilan mahasiswa dan menjadikan siswa memiliki kesadaran dan tanggung jawab yang tinggi dalam berpartisipasi dalam kegiatan pembelajaran.Sedangkan McCarthy (2016) juga menyatakan hasil penelitian bahwa menggunakan Flipped Classroom dapat membantu siswa untuk belajar mandiri dengan mendorong mereka untuk menyesuaikan diri dengan pengalaman belajarnya yang baru.

Dari beberapa penelitian di atas model Flipped Classroom diduga mampu membantu siswa lebih cepat memahami konsep serta dianggap mampu untuk meningkatkan self efficacy serta hasil belajar siswa. Sesuai dengan hasil penelitian Sungkawan (2013) yang menyatakan jika siswa memiliki pemahaman konsep yang tinggi, ia akan selalu berusaha untuk mencapai prestasinya sesuai 
yang telah ditargetkan, dalam hal ini memungkinkan kegiatan pembelajaran akan sukses dalam membantu siswa meminimalisir miskonsepsi dan mengubah miskonsepsi siswa.

Selain dengan menerapkan model pembelajaran yang mendukung, faktor lain yang mempengaruhi keberhasilan siswa di kelas adalah self efficacy atau keyakinan diri. Siswa yang memiliki self efficacy tinggi memiliki peluang besar untuk mencapai keberhasilannya di kelas sedangkan siswa yang memiliki self efficacy yang rendah memiliki peluang kecil untuk mencapai keberhasilannya di kelas.

Berdasarkan sebaran angket telah dijelaskan jika siswa di kelas mengalami kesulitan pada pembelajaran Fisika, baik saat memahami materi, latihan soal, atau eksperimen. Hal tersebut menunjukkan bahwa beberapa siswa masih memiliki self efficacy yang rendah yang ditandai dengan perilaku menyerah saat menemui kesulitan dalam memecahkan masalah, kemudian ditandai dengan perilaku yang muncul saat siswa mendapatkan informasi tentang suatu materi bahwasannya materi tersebut sulit maka siswa cenderung tidak memiliki keyakinan dapat mempelajarinya atau bahkan memecahkan masalah yang berkaitan dengan materi tersebut.

Adapun tujuan dari penelitian ini adalah untuk mengetahui efektivitas dari model pembelajaran Fipped Classroom terhadap self efficacy dan penguasaan konsep siswa. Berdasarkan pemaparan masalah di atas, maka telah dilakukan penelitian yang berjudul "Efektivitas Model Flipped Classroom Pada Pembelajaran Fisika Ditinjau Dari Self Efficacy dan Penguasaan Konsep Siswa".

\section{METODE/EKSPERIMEN}

Penelitian ini merupakan penelitian eksperimen dengan menggunakan desain penelitian Pretest-Posttest Control Group Design. Desain penelitian dapat dilihat pada Tabel 1.

Tabel 1. Desain Penelitian

\begin{tabular}{cccc}
\hline Kelas & $\begin{array}{c}\text { Pre } \\
\text { test }\end{array}$ & Perlakuan & $\begin{array}{c}\text { Post } \\
\text { test }\end{array}$ \\
\hline $\mathrm{E}$ & $\mathrm{O}_{1}$ & $\mathrm{X}$ & $\mathrm{O}_{2}$ \\
$\mathrm{~K}$ & $\mathrm{O}_{3}$ & $\mathrm{Y}$ & $\mathrm{O}_{4}$ \\
\hline
\end{tabular}

Penelitian dilakukan pada dua kelas, yaitu kelas eksperimen yang menerapkan model Flipped
Classroom (X) dan kelas kontrol menerapkan model pembelajaran konvensional (Y). Kelas kontrol menerapkan model pembelajaran konvensional karena model pembelajaran konvensional merupakan model pembelajaran tradisional yang menerapkan metode ceramah dan menempatkan guru sebagai pusat kegiatan pembelajaran (teacher's centered learning). Model ini dianggap kurang mengeksplorasi wawasan siswa dan membuat pasif suasana kelas saat kegiatan pembelajaran.

Populasi pada penelitian ini adalah siswa kelas X SMAN di Bandar Lampung tahun ajaran 2017/2018. Teknik pengambilan sampel menggunakan teknik random sampling (sampel acak) dengan random terpilih dua buah sampel yaitu kelas $X M^{\prime} A_{1}$ sebagai kelas eksperimen $X$ $M I A_{2}$ sebagai kelas kontrol.

Penelitian ini merupakan penelitian eksperimen, variabel pada penelitian ini terdiri dari pembelajaran dengan model Flipped Classroom dan pembelajaran dengan model konvensional/ ceramah sebagai variabel bebas dan self efficacy dan penguasaan konsep siswa pada materi Impuls dan Momentum sebagai variabel terikat.

Data yang diperoleh pada penelitian ini, yaitu skor skala self effecacy dan penguasaan konsep siswa. Setelah data diperoleh, maka dilakukan uji analisis data berupa uji $\mathrm{N}$-Gain. Kemudian dilakukan uji normalitas dengan Kromolov-Smirnov agar mengetahui apakah data berdistribusi normal atau tidak. Selanjutnya dilakukan uji homogenitas untuk mengetahui varian dalam populasi homogen atau tidak dan selanjutnya dilakukan uji Analysis of Covariance (ANCOVA) untuk mengetahui apakah hipotesis dapat diterima atau ditolak.

\section{HASIL}

\section{HASIL DAN PEMBAHASAN}

Telah dilakukan penelitian dengan menerapkan model pembelajaran Flipped Classroom. Adapun dengan pembelajaran Flipped Classroom, siswa terlebih dahulu diberikan sebuah video pembelajaran berisi materi pembelajaran yang harus dipelajari siswa dirumah. Kemudian kegiatan di kelas berupa diskusi dan tanya jawab mengenai materi yang terdapat di video pembelajaran yang diberikan sebelumnya. 


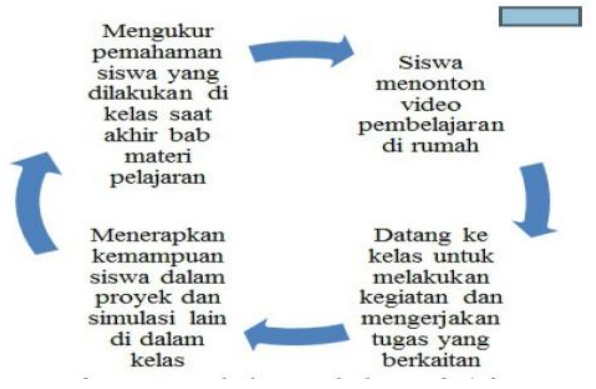

Gambar 1. Langkah-langkah pembelajaran Flipped Classroom (Adhitiya dkk., 2015)

Penelitian ini dilakukan pada siswa kelas $X$ SMA Negeri 16 Bandar lampung, yaitu kelas $X \mathrm{MIA}_{1}$ sebagai kelas eksperimen dan $\mathrm{X} M \mathrm{MI}_{2}$ sebagai kelas kontrol. Proses pembelajaran di-lakukan sebanyak tiga pertemuan. Sebelum proses pembelajaran berlangsung, guru memberikan skala self efficacy dan soal pretest untuk menguji tingkat self efficacy dan kemampuan awal penguasaan konsep siswa dan pada akhir pembelajaran diberikan kembali skala self efficacy dan soal posttest untuk melihat apakah terjadi perubahan tingkat self efficacy dan kemampuan penguasaan konsep siswa setelah diberikan perlakuan.

Sebelum melakukan penelitian, soal terlebih dahulu diujicoba pada siswa kelas XI yang berjumlah 80 siswa yang telah belajar mengenai Impuls dan Momentum yang terdiri dari beberapa sub materi yaitu Impuls, Momentum, Hukum Kekekalan Momentum, dan Tumbukan yang terdiri dari 25 soal. Setelah itu, dilakukan uji validitas dan reliabilitas dan 25 soal yang digunakan dinyatakan valid.

Pada penelitian ini, data kuantitatif yang diperoleh yaitu terdiri dari skor skala self efficacy awal dan akhir serta hasil pretest dan posttest.

Tabel 2. Skor Rata-rata Hasil Tes Awal Skala

\begin{tabular}{clcc}
\multicolumn{4}{c}{ Self Efficacy Siswa } \\
\hline No & Parameter & $\begin{array}{c}\text { Tes } \\
\text { Awal } \\
\text { Kelas } \\
\text { Eksperimen }\end{array}$ & $\begin{array}{c}\text { Tes } \\
\text { Kwal } \\
\text { Kelas } \\
\text { Kontrol }\end{array}$ \\
\hline 1 & Jumlah siswa & 22 & 21 \\
2 & Skor terendah & 50 & 56 \\
3 & Skor tertinggi & 74 & 76 \\
4 & Rata-rata & 64,5 & 63,0 \\
\hline
\end{tabular}

Berdasarkan pada Tabel 2, skor rata-rata tes awal kelas eksperimen adalah 64,5 dan skor ratarata tes awal pada kelas kontrol adalah 63,0 . Skala self efficacy pada kelas eksperimen sedikit lebih besar dari kelas kontrol, tetapi perbedaan tersebut tidak terlalu signifikan.. Dari skor tersebut terlihat bahwa kedua kelas memiliki self efficacy yang sama sebelum diberikan perlakuan.

Tabel 3. Skor Rata-rata Hasil Tes Akhir Skala

\begin{tabular}{clcc}
\multicolumn{4}{c}{ Self Efficacy Siswa } \\
\hline No & Parameter & $\begin{array}{c}\text { Tes } \\
\text { Akhir } \\
\text { Kelas } \\
\text { Eksperimen }\end{array}$ & $\begin{array}{c}\text { Tes } \\
\text { Akhir } \\
\text { Kelas } \\
\text { Kontrol }\end{array}$ \\
\hline 1 & Jumlah siswa & 22 & 21 \\
2 & Skor terendah & 117 & 108 \\
3 & Skor tertinggi & 149 & 135 \\
4 & $\begin{array}{l}\text { Rata-rata } \\
\text { Skor }\end{array}$ & 135,9 & 122 \\
\hline
\end{tabular}

Berdasarkan pada Tabel 3, skor rata-rata tes akhir pada kelas eksperimen adalah 135,9 dan skor rata-rata tes akhir pada kelas kontrol adalah 122,0. Dari skor tersebut terlihat bahwa kedua kelas mengalami kenaikan skor setelah diberikan perlakuan, kenaikan skor rata-rata tes akhir pada kelas eksperimen lebih besar daripada kelas kontrol. Grafik skor rata-rata self efficacy dapat dilihat pada gambar 1 .

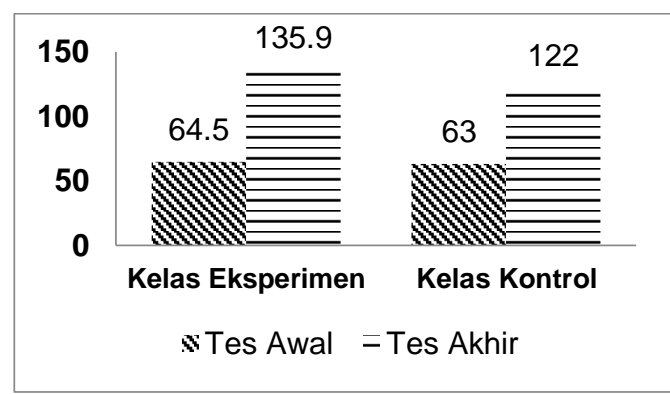

Gambar 1. Skor Rata-rata Skala Self Efficacy

Tabel 4. Nilai Rata-rata Pretest

\begin{tabular}{cccc}
\hline No & Parameter & $\begin{array}{c}\text { Pretest } \\
\text { Kelas } \\
\text { Eksperimen }\end{array}$ & $\begin{array}{c}\text { Pretest } \\
\text { Kelas } \\
\text { Kontrol }\end{array}$ \\
\hline 1 & Jumlah siswa & 22 & 21 \\
2 & Nilai terendah & 32 & 24 \\
3 & Nilai tertinggi & 56 & 68 \\
4 & Rata-rata nilai & 41,3 & 44,8 \\
\hline
\end{tabular}

Berdasarkan pada Tabel 4, nilai rata-rata pretest kelas eksperimen adalah 41,3 dan nilai ratarata pretest kelas kontrol adalah 44,8 . Dari nilai tersebut terlihat bahwa kelas kontrol memiliki nilai 
Pipit Apriyanah, I Dewa Putu Nyeneng, dan Wayan Suana

rata-rata pretest yang sedikit lebih besar daripada kelas eksperimen, tetapi perbedaan tersebut tidak terlalu signifikan. Dari skor tersebut terlihat bahwa kedua kelas memiliki kemampuan pemahaman konsep yang sama sebelum diberikan perlakuan.

Tabel 5. Nilai Rata-rata Posttest

\begin{tabular}{cccc}
\hline No & Parameter & $\begin{array}{c}\text { Posttest } \\
\text { Kelas } \\
\text { Eksperimen }\end{array}$ & $\begin{array}{c}\text { Posttest } \\
\text { Kelas } \\
\text { Kontrol }\end{array}$ \\
\hline 1 & Jumlah siswa & 22 & 21 \\
2 & Nilai terendah & 72 & 56 \\
3 & Nilai tertinggi & 96 & 84 \\
4 & Rata-rata nilai & 82,5 & 69,5 \\
\hline
\end{tabular}

Berdasarkan pada Tabel 5, nilai rata-rata posttest kelas eksperimen adalah 82,5 dan nilai rata-rata posttest kelas kontrol adalah 69,5. Dari nilai tersebut terlihat bahwa kedua kelas mengalami kenaikan nilai setelah diberikan perlakuan, kenaikan nilai rata-rata posttest kelas eksperimen lebih besar daripada kelas kontrol. . Grafik nilai ratarata pretest dan posttest dapat dilihat pada gambar 2.

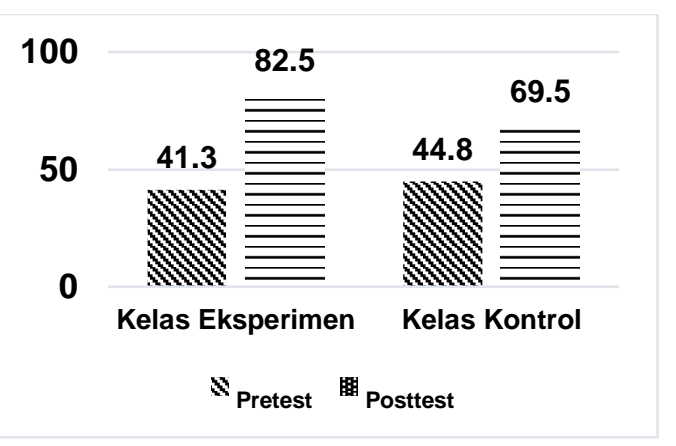

Gambar 2. Nilai rata-rata pretest dan posttest

Selanjutnya, dilakukan uji normalitas untuk mengetahui apakah data yang diperoleh berdistribusi normal atau tidak. Data dikatakan berdistribusi normal apabila nilai Asymp. Sig. > 0.05 , sedangkan data dikatakan tidak berdistribusi normal apabila nilai Asymp. Sig. $<0.05$.

Berdasarkan uji normalitas yang telah dilakukan, hasil uji normalitas skor $N$-Gain skala self efficacy nilai Asymp. Sig. pada kelas eksperimen adalah 0,886 dan nilai Asymp. Sig. pada kelas kontrol adalah 0,999. Kedua nilai Asymp. Sig. di atas melebihi nilai 0,05 yang artinya nilai $N$-Gain pada kelas eksperimen dan kelas kontrol adalah berdistribusi normal.

Selanjutnya, hasil uji normalitas skor $N$-Gain tes penguasaan konsep nilai Asymp. Sig pada kelas eksperimen adalah 0,637 dan nilai Asymp. Sig. pada kelas kontrol adalah 0,976 . Kedua nilai Asymp. Sig. di atas melebihi nilai 0,05 yang artinya nilai $\mathrm{N}$-Gain pada kelas eksperimen dan kelas kontrol adalah berdistribusi normal.

Setelah didapatkan data yang telah berdistribusi normal, selanjutnya dilakukan uji homogenitas. Uji homogenitas bertujuan untuk mengetahui bahwa kedua varian kelompok penelitian homogen atau tidak.

Tabel 6. Hasil Homogenitas N-Gain Skala Self Efficacy

\begin{tabular}{cccc}
\hline $\begin{array}{c}\text { Levene } \\
\text { Statistic }\end{array}$ & df1 & df2 & Sig. \\
\hline 0.129 & 1 & 41 & 0.907 \\
\hline
\end{tabular}

Tabel 7. Hasil Homogenitas N-Gain Tes Penguasaan Konsep

\begin{tabular}{cccc}
\hline $\begin{array}{c}\text { Levene } \\
\text { Statistic }\end{array}$ & df1 & df2 & Sig. \\
\hline 0.129 & 1 & 41 & 0.721 \\
\hline
\end{tabular}

Berdasarkan tabel di atas, pada tabel 6, hasil homogenitas $\mathrm{N}$-Gain skala self efficacy dapat diketahui bahwa nilai Sig. adalah 0,907. Nilai Sig. di atas melebihi 0,05 yang artinya bahwa kedua kelompok data mempunyai varian yang sama atau homogen.

Selanjutnya pada tabel 7 , hasil homogenitas $\mathrm{N}$-Gain tes penguasaan konsep dapat diketahui bahwa nilai Sig. adalah 0,721. Nilai Sig. di atas melebihi 0,05 yang artinya bahwa kedua kelompok data mempunyai varian yang sama atau homogen.

Setelah didapatkan data yang telah homogen, selanjutnya dilakukan uji Analysis of Covariance (ANCOVA) untuk mengetahui apakah hipotesis dapat diterima atau ditolak. 
70 | JIPFRI (Jurnal Inovasi Pendidikan Fisika dan Riset IImiah), Vol. 2, No. 2, November 2018

Tabel 8. Data Hasil Uji ANCOVA Skala Self Efficacy

\begin{tabular}{cccccc}
\hline Kelas & $\mathrm{N}$ & Mean & S.D & Std.error & $\mathrm{F}$ \\
\hline Eksperimen & 22 & 135,775 & 8,7 & 1,763 & 15,28 \\
Kontrol & 21 & 122,140 & 7,5 & 1,805 & \\
\hline
\end{tabular}

Tabel 9. Data Hasil Uji ANCOVA Penguasaan Konsep

\begin{tabular}{cccccc}
\hline Kelas & $\mathrm{N}$ & Mean & S.D & Std.error & $\mathrm{F}$ \\
\hline Eksperimen & 22 & 82.908 & 8,9 & 1.746 & 15.499 \\
Kontrol & 21 & 69.144 & 7,9 & 1.788 & \\
\hline
\end{tabular}

Berdasarkan tabel di atas, pada tabel 8, data hasil uji ANCOVA skala self efficacy dapat diketahui bahwa nilai $F_{\text {hitung }}$ adalah 15,28 yang artinya bahwa nilai $F_{\text {hitung }}$ lebih besar daripada $F_{\text {tabel }}$ yaitu 4,09. Dapat disimpulkan bahwa $\mathrm{H}_{0}$ ditolak dan $\mathrm{H}_{1}$ diterima, maka dalam penelitian ini terdapat perbedaan rata-rata $\mathrm{N}$-Gain antara kelas eksperimen dan kelas kontrol, dimana setelah diterapkan model Flipped Classroom pada kelas eksperimen terdapat peningkatan self efficacy siswa dibandingkan dengan kelas kontrol yang menggunakan model konvensional/ceramah.

Selanjutnya pada tabel 9 , data hasil uji ANCOVA penguasaan konsep dapat diketahui bahwa nilai $F_{\text {hitung }}$ adalah 15,499 yang artinya bahwa nilai $F_{\text {hitung }}$ lebih besar daripada $F_{\text {tabel }}$ yaitu 4,09. Dapat disimpulkan bahwa $\mathrm{H}_{0}$ ditolak dan $\mathrm{H}_{1}$ diterima, maka dalam penelitian ini terdapat perbedaan rata-rata $\mathrm{N}$-Gain antara kelas eksperimen dan kelas kontrol, dimana setelah diterapkan model Flipped Classroom pada kelas eksperimen terdapat peningkatan kemampuan penguasaan konsep dibandingkan dengan kelas kontrol yang menggunakan model konvensional/ ceramah.

\section{PEMBAHASAN}

Berdasarkan pemaparan di atas, menunjukkan bahwa penerapan model pembelajaran Flipped Classroom memiliki pengaruh yang signifikan terhadap peningkatan self efficacy siswa, hal ini dibuktikan dengan melihat gambar 1 skor rata-rata self efficacy kelas eksperimen lebih tinggi dibandingkan dengan kelas kontrol. Selain itu pada kelas eksperimen, siswa yang mendapatkan kategori tinggi lebih banyak dibandingkan dengan kelas kontrol.

Self efficacy berpengaruh pada prestasi belajar siswa karena siswa yang memiliki self efficacy yang tinggi, maka ia memiliki motivasi yang tinggi untuk mencapai prestasi belajar yang baik. Hal ini didukung dengan hasil penelitian Hutagalung (2016) yang menyatakan bahwa self efficacy dan motivasi belajar secara bersama-sama memiliki hubungan yang kuat dengan hasil belajar siswa. Hutagalung menyatakan bila seorang siswa mempunyai self efficacy dan motivasi belajar yang baik akan mempengaruhi hasil belajar. Sehingga dapat disimpulkan bahwa semakin tinggi self efficacy dan motivasi belajar siswa, maka akan semakin tinggi dan baik pula hasil belajar yang dicapai.

Faktor-faktor yang membuat self efficacy siswa yang tinggi menurut Bandura (1977: 4344) adalah 1) pengalaman saat mencapai keberhasilan diri sendiri, 2) pengalaman saat melihat keberhasilan orang lain, 3) dukungan yang positif, 4) keadaan psikologis. Dapat dikatakan bahwa model Flipped Classroom dapat mempengaruhi meningkatnya self efficacy siswa karena dengan menerapkan model Flipped Classroom pada kegiatan pembelajaran dapat memenuhi beberapa faktor yang membuat meningkatnya self efficacy siswa yang telah disebutkan oleh Bandura.

Menerapkan model Flipped Classroom, memberikan pengalaman belajar yang baik bagi siswa, karena dalam proses 
pembelajarannya siswa dibekali dengan media berupa video pembelajaran yang bisa dipelajarinya secara berulang-ulang, dan pada saat kegiatan di kelas siswa dibuatkan kelompok diskusi yang membuat siswa bebas untuk berpendapat.

Dapat dikatakan bahwa siswa di kelas ekperimen berhasil dalam meningkatkan prestasi belajarnya dengan menggunakan model pembelajaran Flipped Classroom karena dipengaruhi oleh pengalaman belajar yang baik, hal ini dibuktikan dengan melihat hasil tes penguasaan konsep siswa di kelas eksperimen lebih tinggi daripada kelas kontrol.

Hal tersebut sesuai dengan faktor-faktor yang membuat self efficacy siswa yang tinggi menurut Bandura pada poin 1) pengalaman saat mencapai keberhasilan diri sendiri dapat meningkatkan self efficacy siswa. Selanjutnya pada poin 2) pengalaman saat melihat keberhasilan orang lain dapat mempengaruhi self efficacy.

Dalam proses pembelajaran menggunakan Flipped Classroom di kelas eksperimen terdiri dari beberapa kelompok diskusi, ketika salah seorang dari suatu kelompok dapat menjawab pertanyaan yang diberikan guru, motivasi siswa dari kelompok yang lain meningkat dibuktikan dengan banyaknya siswa yang berlomba-lomba untuk menjawab pertanyaan selanjutnya yang guru berikan. Maksud dari poin 2) pengalaman saat melihat keberhasilan orang lain yang dirasakan adalah ketika siswa merasa bahwa ia harus belajar lebih baik lagi saat ia mengalami kegundahan ketika melihat temannya lebih unggul dari dirinya, jadi pengalaman itu yang membuat motivasinya meningkat dan dapat membuat self efficacy yang dimilikinya semakin tinggi. Selain 2 poin tersebut, faktor yang mempengaruhi self efficacy siswa meningkat adalah dukungan/feedback yang positif yang diberikan oleh guru ketika siswa mengemukakan pendapatnya dan juga keadaan psikologis siswa.

Berdasarkan uraian di atas, menerapkan model pembelajaran Flipped Classroom pada kegiatan pembelajaran memiliki pengaruh signifikan terhadap peningkatan self efficacy siswa jika dibandingkan dengan menggunakan model konvensional/ceramah. Jadi, dapat disimpulkan bahwa model Flipped Classroom lebih efektif diterapkan pada kegiatan pembelajaran untuk meningkatkan self efficacy siswa dibandingkan dengan model konvensional/ceramah. Semakin tinggi self efficacy dan motivasi belajar siswa, maka akan semakin tinggi dan baik pula hasil belajar yang dicapai.

Selanjutnya, pada gambar 2 menunjukkan bahwa nilai rata-rata posttest kelas eksperimen lebih tinggi dibandingkan dengan kelas kontrol. Selain itu pada kelas eksperimen, siswa yang mendapatkan kategori tinggi lebih banyak dibandingkan dengan kelas kontrol.

Berdasarkan pemaparan di atas, menunjukkan bahwa penerapan model Flipped Classroom memiliki pengaruh yang baik terhadap pemahaman konsep siswa pada materi Impuls dan Momentum, hal ini dibuktikan dengan melihat perbedaan rata-rata $N$-Gain pada tes penguasaan konsep pada kelas eksperimen dan kelas kontrol yang signifikan.

Setelah diberi perlakuan, hasil rata-rata $\mathrm{N}$-Gain pada kelas eksperimen lebih tinggi dibandingkan dengan kelas kontrol. Selain itu, pada kelas eksperimen, $\mathrm{N}$-Gain dikategorikan tinggi dan pada kelas kontrol $\mathrm{N}$-Gain dikategorikan sedang. Jadi, dapat disimpulkan bahwa perbedaan peningkatan penguasaan konsep siswa disebabkan karena adanya perbedaan perlakuan dalam proses pembelajaran yaitu pada kelas eksperimen meng-gunakan model Flipped Classroom sedangkan pada kelas kontrol menggunakan model konvensional/ ceramah.

Penelitian ini juga mengacu pada teori belajar yang mendukung model Flipped Classroom yaitu teori belajar Kontruktivisme (individual learning) dari Piaget dan teori belajar Kontruktivisme sosial (collaborative learning) dari Vygotsky.

Teori belajar Kontruktivisme (individual learning) dari Piaget didefinisikan sebagai pembelajaran yang bersifat generatif dimana siswa akan menciptakan sendiri sesuatu makna/pengetahuan dari apa yang telah dipelajari. Yang menjadi point penting dalam teori belajar kontruktivisme adalah seseorang 
akan membina pengetahuan dirinya secara aktif dengan cara membandingkan informasi atau pengetahuan yang baru didapat dengan informasi atau pengetahuan yang telah dipelajari sebelumnya.

Pada saat menggunakan model Flipped Classroom pada pembelajaran, siswa membangun pengetahuannya sendiri yang berasal dari pengetahuan awal diperolehnya melalui video pembelajaran yang diberikan oleh guru, dimana pada video pembelajaran tersebut disajikan fenomena-fenomena dan beberapa pertanyaan yang harus dijawab mengenai materi yang akan dibahas pada kegiatan pembelajaran di kelas.

Selanjutnya, saat pembelajaran di kelas, siswa akan membandingkan pengetahuan yang telah dimilikinya dengan pengetahuan baru melalui kegiatan eksperimen, sehingga siswa akan menemukan pengetahuan barunya secara mandiri melalui kegiatan eksperimen, sehingga siswa akan menemukan pengetahuan barunya secara mandiri melalui kegiatan eksperimen, dan merangsang siswa untuk berfikir kritis dan kreatif dalam memecahkan suatu masalah serta membuat siswa percaya diri untuk mengemukakan pendapatnya.

Teori belajar lain yang mendukung Flipped Classroom adalah teori belajar kontruktivisme sosial (Collaborative Learning) dari Vygotsky. Teori belajar kontruktivisme sosial (Collaborative Learning) dari Vygotsky menjelaskan bahwa suatu pengetahuan harus dibangun dan dikontruksi secara bersama.

Kontruktivisme dari Vygotsky menekankan bahwa siswa mengontruksi pengetahuan melalui interaksi sosial dengan orang lain. Teori ini mendukung model pembelajaran Flipped Classroom karena proses pembelajaran Flipped Classroom memaksimalkan interaksi satu sama lain dengan cara membentuk kelompok diskusi.

Interaksi sosial terjadi saat kegiatan diskusi di kelas, siswa berdiskusi mengenai pertanyaan-pertanyaan yang berhubungan dengan materi Impuls dan Momentum dan melakukan percobaan yang terdapat pada LKPD bersama kelompoknya. Pada kegiatan ini, siswa akan terbiasa untuk berfikir kritis mengemukakan pendapatnya, beradu argumen dengan kelompoknya, dan menerima umpan balik secara langsung melalui kegiatan diskusi tersebut, sehingga terjadi interaksi sosial yang baik ketika pembelajaran berlangsung.

Model pembelajaran Flipped Classroom dapat meningkatkan kemampuan penguasaan konsep siswa karena dalam proses pembelajarannya berpusat pada siswa (Student Centered Learning) dengan meminimalkan jumlah instruksi langsung dan memaksimalkan interaksi antara siswa dengan siswa yang lain atau antara siswa dengan guru.

Banyaknya interaksi di dalam kelas dapat memicu keterlibatan siswa untuk berpartisipasi dalam kegiatan pembelajaran di kelas. Secara tidak langsung hal tersebut membuat siswa yang pasif menjadi aktif, dimana siswa secara langsung terlibat dalam kegiatan pembelajaran untuk membangun pengetahuannya secara mandiri dan percaya diri untuk mengemukakan pendapatnya.

Hal ini sejalan dengan penelitian Enfield (2013) yang menyatakan bahwa menerapkan model Flipped Classroom pada kegiatan pembelajaran dapat meningkatkan hasil belajar yang diperoleh siswa dan meningkatkan kemampuan siswa untuk belajar secara mandiri.

Dalam menerapkan model Flipped Classroom, siswa terlebih dahulu diminta untuk menonton video pembelajaran di rumah yang diberikan oleh guru sebelum proses pembelajaran berlangsung. Penggunaan media video pembelajaran juga berpengaruh pada peningkatan penguasaan konsep siswa karena siswa dapat menonton video berulangulang sampai memahami apa yang terdapat di video pembelajaran tersebut.

Hal tersebut sejalan dengan penelitian Rahmadi (2014) yang berpendapat bahwa penggunaan media video dalam kegiatan pembelajaran dinilai sebagai suatu hal yang sebaiknya dilakukan oleh seorang guru untuk membantu memecahkan masalah belajar yang dihadapi siswa di kelas, karena sebuah video pembelajaran dapat menyampaikan ilmu sains yang bersifat abstrak menjadi lebih mudah dimengerti. 
Selain itu, media video dapat menyampaikan informasi yang ada didalamnya secara cepat dan mudah diingat, dan memperjelas hal-hal abstrak yang terdapat pada materi Impuls dan Momentum dengan memberikan penjelasan yang realistik.

Hal tersebut akan memungkinkan siswa untuk mengumpulkan data atau informasi, menganalisisnya, menemukan jawaban secara mandiri. Sejalan dengan pendapat Rayandra (2013:23) yang menyatakan bahwa menggunakan media audio-visual salah satunya media video pada kegiatan pembelajaran dapat meningkatkan hasil belajar siswa karena video pembelajaran dapat menyampaikan informasi secara menyeluruh kepada siswa meskipun siswa memiliki gaya belajar yang berbeda-beda. Hal tersebut didukung oleh penelitian Erniwati dkk. (2014) bahwa peserta didik yang menggunakan media berbasis video, mengalami peningkatan hasil belajar dibandingkan yang tidak menggunakan media video.

Perbedaan peningkatan hasil belajar tersebut karena media praktikum berbasis video diduga dapat meningkatkan pemahaman dan motivasi siswa pada materi yang mereka sedang pelajari dan media praktikum berbasis video diduga dapat memberikan gambaran yang lebih jelas dan bermakna mengenai materi yang sedang diajarkan.

Penerapan model pembelajaran Flipped Classroom pada proses pembelajaran memiliki beberapa keunggulan dibandingkan dengan model konvensional, diantaranya adalah jika diterapkan dengan benar, model Flipped Classroom diduga akan memberikan dampak positif untuk prestasi belajar siswa. Model Flipped Classroom memberikan peluang kepada peserta didik untuk berinteraksi baik di dalam maupun di luar kelas. Selain itu, diperkirakan peserta didik menjadi pribadi yang lebih baik, aktif, dan bertanggung jawab dalam kelompok saat memecahkan masalah, dan juga kepercayaan diri mereka untuk menyalurkan ide juga semakin meningkat.

Berdasarkan uraian di atas, menerapkan model pembelajaran Flipped Classroom pada kegiatan pembelajaran memiliki pengaruh signifikan terhadap penguasaan konsep siswa pada materi Fisika Impuls dan Momentum jika di-bandingkan dengan menggunakan model konvensional / ceramah. Jadi, dapat disimpulkan bahwa model Flipped Classroom lebih efektif diterapkan pada kegiatan pembelajaran dibandingkan dengan model konvensional/ceramah.

\section{PENUTUP}

Berdasarkan data hasil penelitian dan pembahasan, dapat disimpulkan bahwa model Flipped Classroom efektif digunakan untuk meningkatkan self efficacy siswa. Hal ini dibuktikan dengan hasil uji ANCOVA penguasaan konsep yaitu nilai $F_{\text {hitung adalah }}$ 15,28 dan $F_{\text {tabel }}$ yaitu 4,09. Hal ini berarti nilai

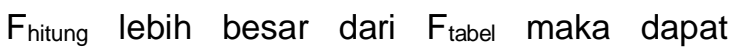
disimpulkan bahwa $\mathrm{H}_{0}$ ditolak dan $\mathrm{H}_{1}$ diterima yang artinya setelah diterapkan model Flipped Classroom terdapat peningkatan self efficacy siswa dibandingkan dengan kelas kontrol yang menggunakan model konvensional/ ceramah. Model Flipped Classroom efektif digunakan untuk meningkatkan penguasaan konsep siswa. Hal ini dibuktikan dengan hasil uji ANCOVA tes penguasaan konsep yaitu nilai $F_{\text {hitung }}$ adalah 15,449 dan $F_{\text {tabel yaitu 4,09. Hal ini }}$ berarti nilai $F_{\text {hitung }}$ lebih besar dari $F_{\text {tabel }}$ maka dapat disimpulkan bahwa $\mathrm{H}_{0}$ ditolak dan $\mathrm{H}_{1}$ diterima yang artinya setelah diterapkan model Flipped Classroom terdapat peningkatan kemampuan penguasaan konsep di-bandingkan dengan kelas kontrol yang menggunakan model konvensional/ ceramah.

Berdasarkan pengamatan secara langsung saat proses pembelajaran dan analisis data, maka peneliti memberikan saran yaitu, model pembelajaran Flipped Classroom dapat digunakan sebagai alternatif bagi guru untuk menciptakan kegiatan pem-belajaran yang interaktif di kelas agar hasil belajar yang dihasilkan sesuai dengan target yang akan dicapai.

\section{DAFTAR PUSTAKA}

Apriyanti, Y., Nyeneng, I., \& Suana, W. Pengembangan Perangkat Pembelajaran Flipped Classroom Pada Materi Getaran Harmonis. Jurnal Pembelajaran Fisika 
74 | JIPFRI (Jurnal Inovasi Pendidikan Fisika dan Riset IImiah), Vol. 2, No. 2, November 2018

Universitas Lampung, 5(2): 69-79.

Bandura, A. (1997). Self-Efficacy The Exercise of Control. Colombia: W.H Freeman and Company.

Erniwati, R. Eso, \& Sitti Rahmia. (2014). Penggunaan Media Praktikum Berbasis Video Dalam Pembelajaran IPA Fisika Untuk Meningkatkan Hasil Belajar Siswa Pada Materi Pokok Suhu dan Perubahannya. Jurnal Sains Dan Pendidikan Fisika, 10(3): 269-273.

Hutagalung, D. D. (2016). The Correlation Between Self Efficacy and Motivation Learning with Mathematics Learning Outcomes Students Class XI IPS SMA Negeri 5 Batam Academic Year 2013/2014. Jurnal Mercumatika: Jurnal Penelitian Matematika dan Pendidikan Matematika, 1(1): 33-43. https://doi.org/10.26486/mercumatika.v1i1 .187

McCarthy, J. (2016). Reflections On A Flipped Classroom In First Year Higher Education. Issues in Educational Research, 26(2): 332-350.

Rahmadi, D., Nyeneng, I D. P., \& Undang, R. (2014). Pengembangan Paket Pembelajaran Sains Bermuatan Nilai Ketuhanan dan Kecintaan Terhadap Lingkungan. Jurnal Pembelajaran Fisika, 2(6): 51-63.

Rayandra, A. (2012). Kreatif Mengembangkan Media Pembelajaran. Jakarta: Referensi Jakarta.

Rindaningsih, I. (2018). Efektifitas Model Flipped Classroom dalam Mata Kuliah Perencanaan Pembelajaran Prodi S1 PGMI UMSIDA. Proceedings of The ICECRS, 1(3): (51-60). https://doi.org/10.21070/picecrs.v113.1380

Rokhaniyah, H. (2017). Flipped Classroom: Can It Optimize Students' Ability To Find Out Main Ideas In Listening Comprehension?. Jurnal Pendidikan, 8(2): 179-182.

Trinova, Z. (2013). Pembelajaran Berbasis Student-Centered Learning Pada Materi Pendidikan Agama Islam. Al-Ta lim Journal, 20(1), 324-335. http://dx.doi.org/10.15548/jt.v20i1.28
Sungkawan, R., Motlan. (2013). Analisis Penguasaan Konsep Awal Fisika Pada Pembelajaran Menggunakan Model Advance Organizer Berbasis Eksperimen Terhadap Hasil Belajar Fisika. Jurnal Pendidikan Fisika, 2(2):73-80.

Sihaloho, Y. E. M., Suana, W., \& Suyatna, A. (2017). Pengembangan Perangkat Pembelajaran Flipped Classroom pada Materi Impuls dan Momentum. EduMatSains, 2(1), 55-71. 